\title{
“The Familiar Style of Decaying Colonial Powers": Irish National Newspapers and Portugal's Colonial Wars, 1961-1974
}

\author{
Jean NF Mercereau \\ Polytechnic Institute of Leiria and University of Minho, Portugal
}

Copyright (c) 2016 by Jean NF Mercereau. This text may be archived and redistributed both in electronic form and in hard copy, provided that the author and journal are properly cited and no fee is charged for access.

\begin{abstract}
The early stages of Salazar's Estado Novo regime in Portugal, between the 1933 constitution and the end of World War II, raised a lot of attention in Ireland as well as in other countries. Salazar's solutions to Portugal's economic and financial crisis were then widely considered as potential solution to many of Ireland's problems. Progressively, however, Ireland lost interest in the Portuguese situation and paid little attention to the evolution of Salazar's dictatorship until the late 1950s in such a way that when colonial wars broke out in Portuguese African territories in the early 1960s, de Valera's Ireland and Salazar's Portugal had been drifting apart for over a decade. More importantly, Portugal's determination to cling to its colonies, causing the country's isolation on the international scene, went against what the Irish Nation essentially stood for. The objective of this article is to consider the coverage by Ireland's three main newspapers - Irish Independent, Irish Press and Irish Times - of Portugal's colonialist policies between 1961 and the fall of the dictatorship in April 1974.
\end{abstract}

Key Words. Portugal, Ireland, António Salazar, Eamon de Valera, Irish newspapers, Colonialism.

Resumen. Las primeras etapas del régimen de Estado Novo de Salazar en Portugal, entre la constitución de 1933 y el final de la Segunda Guerra Mundial, despertaron mucho interés en Irlanda, así como en otros países. Las soluciones de Salazar a la crisis económica y financiera de Portugal fueron ampliamente considerados como posible solución a muchos de los problemas de Irlanda. Progresivamente, sin embargo, Irlanda perdió interés en la situación portuguesa y prestó poca atención a la evolución de la dictadura de Salazar hasta finales de los 1950 de tal manera que cuando las guerras coloniales estallaron en los territorios africanos portugueses a principios de los años 1960, la Irlanda de Valera y el Portugal de Salazar se habían estado distanciando durante más de una década. Más importante aún, la determinación de Portugal de aferrarse a sus colonias, provocando el aislamiento del país en el ámbito internacional, iba en contra de la esencia más profunda de la nación irlandesa. El objetivo de este artículo es considerar la cobertura por parte de los tres principales periódicos irlandeses - Irish Independent, Irish Press y Irish Times - de las políticas coloniales de Portugal entre 1961 y la caída de la dictadura en abril de 1974.

Palabras clave. Portugal, Irlanda, António Salazar, Eamon de Valera, periódicos irlandeses, colonialismo.

1. Portugal is clinging to Angola in the familiar style of decaying colonial powers" (Irish Times editorial, 15 June 1961).

ISSN 1699-311X 
Salazar's Estado Novo dictatorial regime in Portugal was the object of particular attention in many European countries, especially in its early stage, between the new Constitution of 1933 and the end of World War II in 1945. In Ireland, Salazar's early recipes were then widely considered as a potential panacea that had allegedly contributed to putting the country back on track after years of political and economic crisis following the demise of the Republic in 1926. On 4 December 1941, at a time when both Ireland and Portugal were maintaining their neutrality during World War II, and as Dublin was about to open its first diplomatic representation in Lisbon ${ }^{2}$ (Meneses 2005: 16), Eamon de Valera, then Taoiseach for almost a decade, made the following statement in the Dáil (Irish Parliament):

Portugal is a neighbouring country. In certain respects, her geographical situation and her attitude in relation to the present conflict are similar to our own and, no doubt, the problems which confront the two countries, particularly at the present time, have also many points of resemblance. We have all heard of the great advance which Portugal has made under the leadership of her present Premier, Dr. Salazar. The progressive and Christian manner in which the Portuguese Government is handling its economic and other domestic problems has attracted attention and admiration throughout the world and not least, I think, in this country. ${ }^{3}$

With these words, de Valera was not so much reaffirming his own respect and admiration for the Portuguese leader, with whom he shared many characteristics (Meneses 2009: 354), as echoing the general praise of Salazar's handling of Portugal and of the alleged "Christian manner" of the Estado Novo expressed in Irish nationalist newspapers throughout the 1930s (Mercereau 2013: 144, 145). However, from the mid-1940s onwards, Ireland gradually lost interest in the Portuguese situation to such an extent that, when Portugal's colonial wars eventually broke out

2. Ireland's Legation in Portugal, opened in 1942, was only upgraded to the rank of embassy after the April 1974 revolution.

3. Dáil debate, 4 December 1941, available at http://historical-debates.Oireachtas.ie/D/0085/ D.0085.194112040036.html [retrieved 13/11/2014]. in the early 1960s, de Valera's Ireland and Salazar's Portugal, despite their numerous common characteristics, had been drifting apart for over a decade and were left with very little in common. More importantly, Portugal's determination to cling to its colonies went against what Ireland largely stood for since it had become a member of the United Nations in 1955 , and would remain at the heart of growingly irreconcilable differences between both countries through the following decade.

This article, which is part of a wider research project about Ireland's views on Salazar's Estado Novo dictatorship in Portugal (19281974), focuses on the later years of the dictatorship. Although there have been studies comparing the Portuguese Estado Novo in the 1930s with other European countries then governed by dictatorial regimes (particularly Franco's Spain, Hitler's Germany or Mussolini's Italy), few studies have focused on the relationship between Ireland and Portugal throughout the four decades of Salazar's reign, with the notable exception of Filipe Ribeiro de Meneses's Correspondência Diplomática Irlandesa sobre Portugal, o Estado Novo e Salazar in 2005.

The main objective of the present article is not to review Ireland's external policy throughout the 1960s but to analyse how Ireland's main national newspapers presented Portugal's Estado Novo regime in Portugal between the early 1960s and the fall of the regime in 1974, particularly as far as its colonial policy is concerned. With that goal in mind, it consists in trying to determine to what extent their representation of the nature of the regime, and particularly its colonial policy, is biased by their own identities and positions amid the Irish political debate. In order to do so, while all articles with significant reference to Portugal's regime published by Ireland's three main national newspapers, ${ }^{4}$ the Irish Press,

4. In total, besides editorials, 185 articles centered on Portugal between 1961 and 1974 (not including articles about the revolution on 25th April 1974): 39 in the Irish Press, 23 in the Irish Independent and 124 in the Irish Times. This number may be seen as reflecting the interest in the Portuguese situation demonstrated by Irish society at large. 
Irish Independent and Irish Times, have been considered, special interest has been given to the newspapers' editorials as indication of each title's own commitment and opinion.

Eamon de Valera and António de Oliveira Salazar, both born in the $1890 \mathrm{~s},{ }^{5}$ arrived to power in 1932 and remained at the helm of their respective countries for approximately the same period as Salazar was President of the Council without interruption from July 1932 to September 1968 whereas de Valera was Taoiseach between 1932 and 1959 - with two three-year spans in opposition - before going on as President for two seven-year mandates. ${ }^{6}$

Between 1932 and 1945, Portugal and Ireland went through many similar changes: a new constitution based on each leader's traditional and Catholic view of his own nation, ${ }^{7}$ the handling of national fascist movements (The Blueshirts in Ireland and Rolão Preto's

5. Eamon de Valera was born in New York on 14 October 1882 and Salazar in the village of Vimieiro, belonging to the town of Santa Comba Dão, in central Portugal, on 28 April 1889.

6. After taking part in the 1916 Easter Rising, de Valera was elected MP for East Clare after his release from jail the following year and became President of the illegal Irish Parliament in 1920 before leading the opposition to the Treaty after 1922. With his Fianna Fáil party, which he founded in 1926, Eamon de Valera won six successive general elections between February 1932 and May 1944, losing to John Costello's Fine Gail in February 1948. Back in office between June 1951 and May 1954, he became Taoiseach again in March 1957 before stepping down in 1959 to become President of the Irish Republic until 1973. As for Salazar, he was first made Minister for Finances in April 1928 and was appointed President of the Council in July 1932, remaining in power until September 1968, two years before his death.

7. According to Meneses, the Portuguese dictator's views can be seen as "a distillation of Catholic and counter-revolutionary politics, mostly taken from Papal Encyclicals and from French thinkers such as Gustave Le Bon and Charles Maurras" (Meneses 2009: 83). As for the ideology behind the Constitution of Ireland, it has been described by Basil Chubb as "a mixture of liberal and democratic elements derived from the British tradition, with principles and precepts drawn from Catholic social theory and, in particular, papal encyclicals" (Chubb 1991: 45).
Nationalist Syndicalists in Portugal), the issue of the Spanish Civil War (in which Salazar's support was crucial to the Nationalists' victory while de Valera imposed Ireland's neutrality despite strong pressures to intervene on Franco's side $^{8}$ ) or neutrality during World War II. ${ }^{9}$ Indeed, until the mid-1940s, Salazar had many admirers in Ireland, including de Valera himself and his close adviser and minister Sean McEntee. ${ }^{10}$

In particular, while both the Irish Press and the Irish Independent repeatedly echoed this general feeling of admiration for the changes brought to Portugal's economic situation by the Portuguese dictator, the Irish Times expressed much more skepticism towards the Portuguese dictator's alleged achievements (Mercereau 2013: 140-2).

On the whole, three main periods may be defined as far as Ireland's interest in the Portuguese Estado Novo is concerned, as the following chart, based on editorials dedicated to the Portuguese situation in all three main Irish newspapers at the time, illustrates:

Editorials on Portugal in Irish national newspapers, 1932-1974

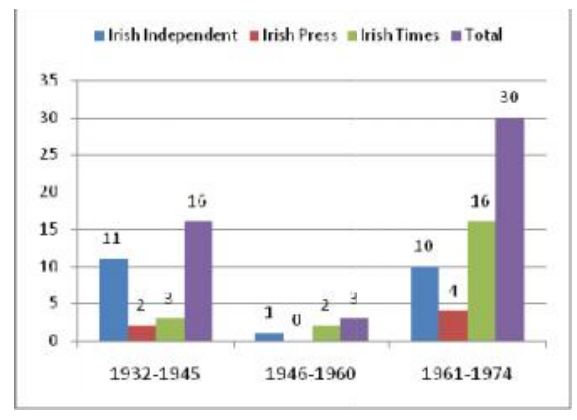

8. From the leading opposition party Fine Gael and the Catholic authorities, as well as newspapers such as the Irish Independent.

9. In quite different circumstances, however, because while Portugal's neutrality was strongly encouraged by the allies in order to keep Franco's Nationalist Spain out of the conflict, de Valera's decision was strongly criticized by Churchill, which would lead to a bitter exchange between the Taoiseach and the British Prime Minister in May 1945. Besides, while Ireland was, on the whole, quite faithful to the allies' cause, Salazar's Portugal went on doing business with Germany until 1944, when it eventually gave in to the allies' demands (Rosas 1994: 320).

10. The Irish Examiner, 24 June 2006. 
On the one hand, between both Salazar and de Valera's arrival to power in 1932 and the end of World War II in 1945, Portugal clearly raised interest in Ireland with most editorials by the Irish Independent and, to a lesser extent and according to different political purposes, the Irish Press, enthusiastically praising the recipes brought forward by Portugal's "economic wizard" (Irish Independent, 12 February 1938). Indeed, the early stages of the Estado Novo between 1932 and 1945 regime saw both Fianna Fáil - in power throughout the period - and Fine Gael - the main opposition party - compete for political capital to be gained from comparisons with the Portuguese situation. On the other hand, the post-war years, particularly until the outbreak of the war for independence in Angola in 1961, show a general loss of interest in the Portuguese situation, ${ }^{11}$ possibly due to the general perception that Salazar's recipe was no longer

11. With exceptions for events which were the object of a series of articles in all three newspapers, such as the diplomatic crisis between Portugal and India and the subsequent invasion of Goa by Indian troops in December 1961, the June 1958 presidential election in which General Delgado threatened to overrule Salazar and, above all, Eamon de Valera's two-day official visit to Portugal and meeting with Salazar in September 1953. On that occasion, the fact that the seen as a panacea, to the hardening of Salazar's dictatorial rule and to the fact that Ireland and Portugal, after their integration into the United Nations in 1955, followed radically opposed paths on the international scene. Actually, following the country's membership of the UN in 1955, and particularly under Séan Lemass from 1959 onwards, Ireland played a particularly active role in the United Nations' decolonisation policies (Lee 1990: 369).

The third period, between the involvement of Portugal in colonial wars in Africa and the fall of the regime in April 1974, seems to have been followed with particular attention in Ireland judging from the abundance of editorials focusing on Portugal in all three Irish newspapers (thirty over the period). Before seeing in detail what these articles may reveal of the perception of the Portuguese situation, it is important to take into account the characteristics of each of the three newspapers at the time:

.$/$ de Valera was accused of thinking of applying to Ireland some of Salazar's recipes that would have been welcome by many in the 1930s is another indication of the evolution of the general perception of the Portuguese regime in Ireland ("Is Taoiseach considering Salazar system ?”, The Irish Times, 13 October 1953).

The Irish Independent, the Irish Press and the Irish Times, 1961-1974

\begin{tabular}{|c|c|c|c|}
\hline TITLE & ORIGIN & $\begin{array}{c}\text { CIRCULATION } \\
1961-1974\end{array}$ & CHARACTERISTICS \\
\hline $\begin{array}{c}\text { The } \\
\text { Irish } \\
\text { Independent }\end{array}$ & $\begin{array}{c}\text { Founded in 1891 following } \\
\text { scission within Nationalist } \\
\text { Party }^{12}\end{array}$ & $\begin{array}{c}1961: 170,000 \\
1974: 173,000\end{array}$ & $\begin{array}{c}\text { Faithful supporter of pro- } \\
\text { Treaty Fine Gael and critical of } \\
\text { de Valera }\end{array}$ \\
\hline TheIrishPress & $\begin{array}{c}\text { Founded in 1932 by de Valera } \\
\text { to support his ideal of a } \\
\text { Catholic, Gaelic and } \\
\text { Republican Ireland }\end{array}$ & $\begin{array}{c}1961: 118,000 \\
1974: 92,000\end{array}$ & $\begin{array}{c}\text { Supporter (unofficial organ) of } \\
\text { FiannaFáil and de Valera }\end{array}$ \\
\hline $\begin{array}{c}\text { TheIrish } \\
\text { Times }\end{array}$ & $\begin{array}{c}\text { Founded in 1859 as organ of } \\
\text { the Protestant and Unionist } \\
\text { Ascendancy of Dublin }\end{array}$ & $1961: 35,000$ & $\begin{array}{c}\text { Originally unionist, still mostly } \\
\text { opposed to de Valera but more } \\
\text { and more independent }\end{array}$ \\
& 14000 & \\
\hline
\end{tabular}

Source: Joint National Readership Survey (www.jnrs.ie), Brown 1971, Horgan 2001. 
The fact that these three newspapers represent different traditions within Ireland's politics in the twentieth century, as well as their impressive combined circulation $(323,000$ in 1961 and 335,000 in 1974) - particularly considering Ireland's sparse population over the period ${ }^{15}$ - seem to make the papers' views on the Portuguese situation fairly representative of the general perception of Irish society at the time.

As has already been mentioned, Ireland and Portugal both joined the United Nations in 1955, but they were by then following increasing divergent paths. In Ireland, Eamon de Valera, back in power as Taoiseach following

12. In December 1891, following a scission within the Nationalist Party after the scandal involving its leader Charles Parnell, his supporters founded The Irish Daily Independent which became the Irish Independent in 1905 and soon replaced the Freeman's Journal as "the voice of the increasingly wealthy, articulate and mildly nationalist Catholic middle class" (Horgan 2001: 1).

13. Launched by Eamon de Valera with funds mostly raised in the United States, the Irish Press always remained closely linked to the de Valera family through his son Vivion and grandson Eamonn, in 1951 and 1982 respectively. Besides the Irish Press, the Irish Press group also included an evening (the Evening Press, 1954) and a Sunday newspaper (the Sunday Press, 1949), all highly successful until the early 1960s. Due to both the evolution of Irish society and the management of the newspapers, the group finally closed down in 1995. The demise of the Irish Press Group is often seen as the symbol of Ireland's evolution between the 1960s and 1990s.

14. Founded in 1859 as the organ of the unionist and Protestant Ascendancy of Dublin' the Irish Times only began to appear as a credible option to Catholic and nationalist readers in the 1930s. Strongly opposed to Home Rule, it managed to survive the independence of the country in 1922 and progressively succeeded in accompanying the evolution of a traditionally Catholic and nationalist country in such a way that it would become one of its major references by the late 1960s, under Douglas Gageby's editorship.

15. According to the Central Statistics Office of Ireland (www.cso.ie), the population of Ireland was 2,808,341 in 1961 (its lowest ever) and 2,972,248 in 1971. the 1957 general election, stepped down in 1959 to become President, letting Sean Lemass (in October 1961 and November 1965) and Jack Lynch (in June 1969) lead Fianna Fáil to victories until a Fine Gael-led coalition put an end to Fianna Fáil's sixteen uninterrupted years in power in 1973, when Ireland entered the European Community, thirteen years before Portugal. In the meantime, Ireland had moved a final step towards complete independence from Britain with the proclamation of the Republic and the subsequent exit from the Commonwealth in 1949 (Lee 1990: 300).

In Portugal, following domestic threats to the regime in the late 1950s (Rosas 2012: 236-46), 1961 is often considered Salazar's annus horribilis with, among other setbacks, the hijacking of the Santa Maria liner by Portuguese opponents led by Henrique Galvão in January, the beginning of the colonial war in Angola in February, the overwhelming vote ${ }^{16}$

at the General Asssembly of the UN to condemn Portugal's colonialist policy in Angola on 23 March, an attempted coup led by the Minister for Defense, Botelho Moniz, in Lisbon in April and the invasion of the Portuguese territories of Goa, Damião and Diu by India, putting an end to years of diplomatic conflict between Lisbon and New Delhi, in December. All these events led, during that year, to many articles in Irish newspapers as well as a considerable number of reports by $\mathrm{J}$. $\mathrm{W}$. Lennon, then Ireland's chargé d'affaires in Lisbon (Meneses 2005: 368-420).

Logically, the events that led to more articles in the Irish newspapers over the period, besides those directly dealing with the escalation of the colonial wars in 1961 (Angola), 1962 (Guinea) and 1963 (Mozambique) and the subsequent isolation of the Portuguese regime on the international stage, are related to the true nature of the Estado Novo regime and the increasing signs of opposition to it, Salazar's personality and characteristics, his retirement from power in 1968 and death two years later and the changes expected from his successor,

16. With 79 votes in favour (including Ireland's), 2 against (Spain and South Africa) and 9 abstentions (including France and the UK). 
Marcelo Caetano, from 1968 onwards. As far as editorials are concerned, the following chart shows their distribution by year over the period:

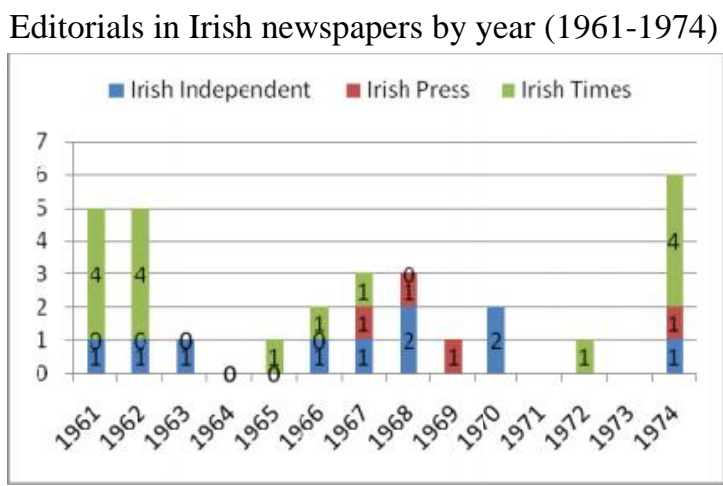

Again, the three newspapers selected for this study reveal different characteristics as well as journalistic options. Above all, a closer look at their positions directly expressed towards Portugal reveals differences in their attitudes. The Irish Press, as always controlled by de Valera, confirmed the general tendency in the 1930s by showing a strong interest in Salazar's alleged "achievements" before being clearly indifferent all through the 1940s and 1950s and demonstrating a relative resurgence in interest in Portugal over the period, with a total of 39 articles, plus four editorials focusing on Portugal between 1961 and 1974. Above all, the Republican title's editorials reveal a surprising leniency when commenting on the Portuguese regime's colonial policy at a time when Salazar's only supports came from the segregationist South African regime, Franco's Spain and Ian Smith's Rhodesia:

It is sometimes assumed that Portugal's attitudes to Africa are identical with those of South Africa. Nothing could be further from the truth. South Africa insists on Apartheid and segregation, Portugal permits, and even in some places encourages, integration (30 December 1967).

A year later, on 20 September 1968, the Irish Press's mild condemnation of Portugal's policy essentially focused on economic terms: "It is one of the most startling paradoxes of our time that the poorest country in Western Europe can afford to spend over $£ 100$ million a year in fighting colonial wars". After Marcelo Caetano succeeded Salazar in September 1968, the newspaper praised the new leader's attempt to break with his predecessor's policy while linking the situation in Portugal's overseas territories to the recent outbreak of violence in Northern Ireland, on which the Irish Press focused its attention:

It is on the explosive issue of the overseas "provinces" of Angola and Mozambique that Dr Caetano has broken most obviously with the Salazar line by hinting at future "autonomy" and even a "political settlement". [...] As we have seen in the North of Ireland, liberalisation cannot always be rushed through without fear of a violent backlash from vested interests (25 October 1969).

On the whole, more than a real sympathy towards Portugal's colonial policy, which would be particularly surprising coming from a newspaper essentially dedicated to defend de Valera's ideal of a Catholic, Gaelic, rural and self-sufficient Ireland, the Irish Press's relative indifference towards the question of Portugal's regime and its mild criticism of Salazar's colonial policies may be justified by the fact that, from the late 1960s onwards, the newspaper was more committed to the increasingly complex question of Northern Ireland and its growing repercussions in the Republic. Besides, the Irish Press was always "not a Fianna Fail mouthpiece, but a de Valera mouthpiece", as Tim Pat Coogan puts it (Coogan 1999: 444), which could partly explain why the newspaper may have been somewhat reticent to openly criticize Salazar, a leader to whom de Valera showed many marks of respect and admiration (Meneses 2005: 24-6). Moreover, trying to get political gains by associating de Valera to Salazar, as the Irish Press did on many occasions in the 1930s (Mercereau 2013: 142), was by then totally out of the question and, considering Salazar's growing unpopularity, could turn out to be counter-productive.

The Irish Independent was the keenest supporter of Salazar's recipe in the 1930s (Mercereau 2013: 140), not only because it was impressed by Portugal's alleged economic and financial recovery and by Salazar's ability to transform his country "from a state of chaos into a Model Nation" (28 February 1939), but also because it took the opportunity to oppose what it saw as de Valera's failure to Salazar's success, thus 
"showing the world what a small state can do when it is well governed" (1 March 1938). After years of relative indifference between 1946 and 1960, the Irish Independent regained interest in the Portuguese situation from the early 1950 s but, somehow like its rival the Irish Press, with which it was in disagreement on most domestic issues, was far from being openly hostile to the Portuguese regime to which it dedicated a total of ten editorials besides 23 articles exclusively dedicated to the Portuguese situation, including seven full-page articles about the Pope's visit to Fátima in May 1967.

In particular, the Irish Independent repeatedly insisted on the need to distinguish between Portugal and other segregationist regimes such as South Africa, as it did in an article of opinion in August 1961: "It is indeed a pity that the Portuguese, who have followed the principles of racial equality, are pilloried at the UN alongside the South African champions of white supremacy" (1 August 1961). A longtime supporter of Salazar, the newspaper then mildly warned the Portuguese dictator against the dangers of the path he was following, not without reminding its readers of all the credit owed to his work in the thirty years spent at the helm of his country:

Dr Salazar can point to Portugal's long centuries of association with its colonies, and to its sane and admirable policy of integration - even if the practice is less advanced than the theory. But that is clearly not enough in the Africa of this decade. Dr Salazar must surely look to a new solution to his problems in Africa, just as surely as he cannot indefinitely repress all discontent within Portugal itself. It would be a tragedy if he bequeathed to Portugal the instability that thirty years ago he took up office to check (Irish Independent editorial, 15 November 1961).

A few weeks later, the newspaper went a step further in its defence of Salazar, for the sake of the alleged stability and prosperity brought to his country by the Portuguese dictator:

Dr Salazar is neither the Fascist nor the tyrant that some would make him out to be. He put his country on its feet after a time of anarchy. He brought stability to its finances and social justice to its administration. It is not his fault that he has failed to root out much appalling poverty, for Portugal has been poorly endowed by nature. His error has been to rule too long with an iron hand (Irish Independent editorial, 2 January 1962).

Even when Portugal was widely condemned for clinging to its overseas territories, the Irish Independent seems to justify Salazar's treatment of the African populations by reminding that the essence of the regime is based on systematically denying all freedom to all the nation's citizens alike, without discrimination of any kind:

It is worth remembering that the Portuguese were never racialists. There is no social Apartheid in either Angola or Mozambique. If African nationalism is denied the right to express itself this is not because those who wish to speak are black but because they are opponents of the regime and Dr Salazar keeps a tight rein on all opposition whether at home or in Africa (Irish Independent editorial, 25 July 1963).

After some years without expressing any opinions on the Portuguese question, the Independent eventually turned to the Estado Novo again after a stroke forced the dictator to leave power:

Despite its highly publicised pursuit of gradual (and highly selective) assimilation, - a kind of institutionalized Uncle-Tomism - with its claim of equality and citizenship for a minority, Portugal maintains the last of the great European colonial empires. Its policies are not helpful to either white or black (Irish Independent editorial, 21 September 1968).

But again, the newspaper seems to reach a lenient verdict at a time when even some of Salazar's staunchest supporters were beginning to question the sensibility of his policy (Labourdette 2000: 603):

Dr Salazar must be judged in the context of the history of his own country. It would be wrong to label him and his deeds with ill-defined international terms such as "right", "left", "centre" or reactionary. He was a man Portugal badly needed when she placed him in power. And the country needed him for a long time after that. [...] The men who come after him will have to build on what he saved from history (Irish Independent editorial, 21 September 1969).

Of the three newspapers under scrutiny here, the Irish Times had been the most critical of the 
Portuguese Estado Novo regime since Salazar's arrival to power in 1932. Even in the 1930s, when its rivals praised the efficiency of Salazar's measures and the essentially Christian nature of his regime, the originally Unionist newspaper insisted on reminding its readers of the real character of the Estado Novo. ${ }^{17}$ As years went by, the Irish Times maintained more interest in the Portuguese situation than its rivals, with the publication of many articles about the opposition to the regime and the diplomatic crisis between Portugal and India concerning the so-called Portuguese State of India; it published a total of 124 articles about Portugal between 1960 and 1974, including 16 editorials, which represents more than its competitors together. As early as 1957, an Irish Times' editorial expressed the view that

a mother country in which political parties are banned, in which the 20 daily newspapers are subject to censorship, [...] such a country is hardly fitted to be the cradle of democracy for the nationalist aspiration of the people of Asia and Africa (Irish Times editorial, 5 November 1957).

Two years later, the newspaper's verdict about the nature of Salazar's regime is particularly blunt: "The fact is that Portugal is a dictatorship, with only some of the trappings of democracy" (Irish Times editorial, 8 May 1959).

The first signs of violent repression against Angola's nationalist movements by the Portuguese authorities naturally led the Irish Times to criticize the management of its overseas territories by the Estado Novo in strong terms:

The prime cause of unrest in Angola is Portugal's own policy. By calculated exploitation and repression, she has developed there a smouldering resentment which needs only a spark to make it burst into flame. To blame other countries now for striking the spark,

17. By questioning, for instance, the plebiscite on the 1933 constitution in which every abstention counted as a yes vote, wondering at the systematic absence of opposition candidates in the general elections of November 1942 and November 1945 or underlining the role of censorship all through the 1930s and 1940s. or to pretend that they could put the fire out once lit, is totally unrealistic (Irish Times editorial, 1 July 1961).

Furthermore, as early as 1961, and as both its competitors still credited Salazar with mitigating circumstances well into the 1960s, the newspaper considered the condition of the African population in Portuguese African territories even worse than in South Africa: "There seems little doubt that the policy adopted in Angola is as savagely cruel and repressive as that of South Africa. A good deal more so, in fact . [...] Angola's negroes are quite frankly slaves" (Irish Times editorial, 1 July 1961)

On the whole, the Irish Times strived once again to put an end to the myth (Léonard 1996: 9-76; Mesquita 2007: 16-20) of Salazar as a "dictator malgré lui" (Irish Press, 12 January 1938) or as a "non-violent, gentle dictator" (Irish Independent, 10 March 1938) as transmitted by both the Irish Independent and the Irish Press for many years, and insisted on the true nature of the regime and its leader:

Portugal is clinging to Angola in the familiar style of decaying colonial powers. [...] The romantic simplicities which a Salazar or a Franco can afford - which usually, in practice, boil down to a brutal repression of all who do not agree with them - have a charm for those who are weary of the crabwise workings of democracy. There is even the persisting legend of Dr Salazar as an economic wizard: a glance at Portugal's living standards might cause these admirers to think afresh (Irish Times editorial, 15 June 1961).

Having condemned colonialist policies coming from other countries, the Irish Times insisted on applying the same treatment to Portugal: "The anti-colonial wind has not been tempered for Britain, France, Holland or Belgium - why should Portugal expect special treatment for one of the more glaring cases of exploitation?" (Irish Times editorial, 12 February 1962). Indeed, by the mid-1960s, the Irish Times was the only one of the three newspapers to insist on the anachronism of Salazar's regime:

The most reticent of dictators never bothers to answer criticism - but this does not alter the fact that he has criticism to answer. His country's problems have outgrown his solutions for them, 
and his arid despotism grinds the faces of the poor. All this he has done with the best of intentions. There is, presumably, still a train to Coimbra: it would be a pity if he were to miss the last one" (Irish Times editorial, 12 November 1966).

In March 1974, only a few weeks before the military coup that would put an end to the dictatorship, an Irish Times' editorial entitled "Out of Africa" questioned the true determination of Salazar's successor to actually change the nature of the regime:

Portugal is an impoverished country which has not yet gazed on the realities of the twentieth century. She will have to come to terms with it in a matter of months, not of years. Her Prime Minister says that he has the faith that "unity, serenity and the national awareness of the people ... will finally triumph over this crisis". He will have to prove his belief. That remains to be seen. Portugal has much leeway to make. It's simple enough, if she looks at it straight. All she has to do is to get out of Africa (Irish Times editorial, 16 March 1974).

Three main conclusions may be drawn from this brief analysis of the perception of the evolution of the New State regime in Portugal by Ireland's three major newspapers between the beginning of the colonial conflicts in 1961 and the demise of the regime in 1974. Firstly, the resurgence of interest in a Portuguese situation that had been in the forefront of Irish media and politics in the 1930s, after years of relative indifference following the end of World War II and through most of the 1950s, reflects the evolution of the interest shown by the political actors as well as by the population in general. This may be due to the fact that, from 1960 onwards, Portugal openly stuck to an unambiguous colonialist policy which could hardly be expected to find much support from a country with a history such as Ireland's. At the same time, considering Ireland's historical struggle for independence from Britain as well as its crusade against imperialist policies within the frame of the UN from the mid1950s onwards, Portugal's policy, which led to find itself isolated ("proudly alone", as Salazar himself put it) on the international scene, had every reason to raise interest, if not approval, in Ireland.
Secondly, the harshest rejection and condemnation of the colonialist policies of the New State regime came from the newspaper which is historically the least committed to Ireland's fight for independence. In other words, whereas both the Irish Press and the Irish Independent were, in a way, born from Ireland's nationalist aspirations, the Irish Times was founded in 1859 to speak for "Irishmen loyal to the British connection and proud to share in the destinies of the only firstrate power in Europe that has known how to combine social order with individual freedom (Irish Times editorial, 28 March 1859). What may at first seem a paradox, however, may be explained by the fact that, unlike its two rivals, the Irish Times never took part in the traditional fight for power between Fine Gail and Fianna Fail during the twentieth century in Ireland, which may have given the newspaper more leeway in its commitments and positions. Besides, the purely journalistic evolution of the Irish Times, first in the years following the foundation of the Irish Free State in 1922 and, above all, under Douglas Gageby's editorship from 1963 onwards, allowed it to acquire the status of respectable national institution (Mercereau 2002: 8) as well as a truly international dimension hardly comparable to that of its competitors, much more focused on the national divisions. As such, the Irish Times clearly distinguishes itself from, on the one hand, the partisan Irish Press, constant in its support of de Valera's Fianna Fáil (O'Brien 2001: 29-55) and, on the other hand, the Irish Independent, which confirmed to be, "first and foremost, a commercial undertaking" (Brown 1971: 40).

Thirdly, the condemnation of Portugal's international policy in the 1960s and early 1970s by the Irish Times and, to a lesser extent, the Irish Independent and Irish Press, must be seen as reflecting the growing alienation between both countries at the time, especially considering Ireland's history. The revolution of 25 Abril 1974, which led to the implementation of a democratic regime, and Portugal's membership of the European Community in 1986, alongside Spain, would help to restore the links between two countries 
which have since gone through many similar ordeals. ${ }^{18}$

\section{Works Cited}

Brown, Stephen. 1971 (1937). The Press in Ireland: a Survey and a Guide. New York: Lemma Publishing Corporation.

Chubb, Basil. 1991. The Government and Politics of Ireland. London: Longman.

Coogan, Tim Pat. 1999. Eamon de Valera: the Man who was Ireland. New York: Barnes \& Noble.

Costa Pinto, António. 1995. Salazar's Dictatorship and European Fascism. Boulder: Social Science Monographs.

Horgan, John. 2001, Irish Media, a Critical History since 1922. London: Routledge.

Labourdette, Jean-François. 2000. Histoire du Portugal. Paris: Fayard.

Léonard, Yves. 1996. Salazarisme et fascisme, Paris, Chandeigne.

Lee, Joseph. 1990. Ireland 1912-1985, Politics and Society. Cambridge: Cambridge University Press.

Mercereau, Jean. 2002. Évolution et singularités d'un journal de référence irlandais: l'Irish Times 1859-1999. Paris: la Sorbonne Nouvelle.

. 2013. "The Most Christian State in the World: Irish Nationalist Newspapers and the Estado Novo 1932-1945". Diácritica 2013, volume 27. Braga: Scielo. 135-47.

Mesquita, António Pedro. 2007. Salazar na história política do seu tempo. Lisbon: Caminho.

O’Brien, Mark. 2001. De Valera, Fianna Fáil and the Irish Press. Dublin: Irish Academic Press.

Ribeiro de Meneses, Filipe. 2005. Correspondência Diplomática Irlandesa sobre Portugal, o Estado Novo e Salazar.Lisbon: Ministério dos Negócios Estrangeiros. .2009. Salazar, a Political Biography. New York: Enigma Books.

Rosas, Fernando.1994. O Estado Novo, in Mattoso, José (ed.) História de Portugal. Volume VII. Lisbon: Editorial Estampa. 2012. Salazar e o poder. Lisbon: Tinta-da-China.

\section{Editorials quoted}

"Dr. Salazar's State", Irish Times, 5 November 1957: 5.

"Trouble in Portugal", Irish Times, 4 May 1959: 7.

"Angola", Irish Times, 15 June 1961: 7.

"Salazar and Angola", Irish Times, 1 July 1961: 10.

"Dr. Salazar", Irish Independent, 15 November 1961: 7.

"Revolt in Portugal", Irish Independent, 2 January 1962: 7.

"Dictators' Marriage", Irish Times, 12 February 1962: 7.

"Portugal in Africa", Irish Independent, 25 July 1963: 10.

"The Train to Coimbra", Irish Times. 12 November 1966: 9.

“After Salazar?”, Irish Press, 30 December 1967: 4.

"Portugal", Irish Press, 20 September 1968: 8.

"Portugal after Salazar", Irish Independent, 21 September 1968: 12.

"Portugal at the Polls", Irish Press, 25 October 1969: 8.

"Out of Africa", Irish Times, 16 March 1974: 11.

Received 12 December 2015 Last version 23 February 2016

Jean NF Mercereau is Associate Professor at the School of Technology and Management, Polytechnic Institute of Leiria (Portugal) and researcher in the Department of English and North American Studies, Institute of Letters and Human Sciences, University of Minho (Braga, Portugal).

18. Besides economic and social problems, the breakout of the financial crisis in 2007 led both Ireland and Portugal to ask for a bailout, in November 2010 and April 2011 respectively. Three years later, both countries opted to exit the programme without the help of a precautionary line (Ireland: December 2013; Portugal: June 2014) with a varying degree of success. 